\title{
How Does the Students' Readability in Mastering English Material?
}

\author{
Atik Rokhayani \\ Universitas Muria Kudus \\ atik.rokhayani@umk.ac.id
}

\begin{abstract}
In English class, the teachers/lecturers have to take a big chance in managing their students well. Managing the class is not an easy thing to do. The lecturers have to use appropriate techniques to gain the students' attention. In university level, the students are the focus in English teaching and learning process. They have many different characteristics and readability. From this atmosphere, the lecturer has to be ready for those differences. In selecting the English materials, the lecturer should consider based on the students' needs. The paper aims at investigating the students' readability in English class in mastering English material. It focuses on Intermediate Grammar Class. It describes the students who like watching English movies. The material focuses on simple past tense. The method of this study is descriptive qualitative research. This result shows that the mean score from the students who like watching English movies is 77.83. From the mean score, the mastery of simple past tense of the students who like watching English movies can be categorized as good. It can be used as the contribution to English teaching and learning process and reference for further researchers in doing similar research.
\end{abstract}

ARTICLE HISTORY

Received 15 April 2017

Accepted20 August 2017

\section{KEYWORDS}

Students' Readability

\section{Introduction}

In this globalization era, the students are offered to do many activities online and offline world. By using the online world, the students can communicate to the people around the world. The students can practice English directly to the native speakers. They can practice by speaking or writing the comments. The students show positive and good attitudes in using the internet as a learning media (Srichanyachon, 2013). In the offline world, the students can practice English with their teacher/lecturers and friends. The condition is improved from time to time. In past decades, when the internet is rare, the students only depend on their lecturers and books. The development of the Information and Technology helps and supports the aspect of education. Many students tend to use the internet daily as their needs.

Universitas Muria Kudus is one of the private universities located in Central Java, Indonesia. It is located in Kudus regency. In Universitas Muria Kudus, the students are free to join students' activities. One of the students' activities is ESA (English Students Association). It is the forum for English Education Department 
students. In ESA, the students do many activities related to English. There are many activities conducted by ESA, for example, English debate, English Friendly Night, English discussion, and others. By joining ESA, the English Education Department students can improve their English skills and components. They are practicing speaking in English and delivering the ideas in English. Although the program in ESA is for improving students' English competence, not all students of English Education Department join in ESA.

In English class, the students are asked to enhance their English skills and components by doing some activities. The activities are relating to their readability toward English among others are listening to English songs, watching English movies, reading English magazine/newspapers, etc. The students seem to enjoy in such activities. They can improve their English without constraint from other people. In this case, the lecturers can ask the students to take a role in doing those fun activities.

The paper focuses on the students' readability in Intermediate Grammar Class in this study. Intermediate Grammar Class is one of the compulsory subjects for the students of Universitas Muria Kudus. It has four credits. The writer of this study will describe one of the students' readabilities. It is watching English movies. Watching movies will be explored in this study since it can help the students in mastering English. The writer only focuses on mastering simple past tense.

In Intermediate Grammar Class, the lecturer has to be active in the teaching and learning process because the students have different readabilities. In comprehending the text, the students have a different perspective. To measure the difficulty of the text, the students use the readability formula (Begeny \& Greene, 2014). So, the students have to be one of the topics discussed is simple past tense. Simple past tense is considered the vital tense because it is used to express past events.

The lecturer of Intermediate Grammar Class has to be responsible toward the students understanding of the materials. She/he has to be active in teaching since the students come from different cultures and background of readability. The students' cultures and readability influence their understanding of mastering grammar. Some students think that grammar is complicated since they have to comprehend the topics. In the level of understanding, there are types of students who are easily master the materials, and some others need time to master the materials. This condition makes the teaching and learning process vary, and it makes the teacher/lecturer adapt toward the atmosphere.

This paper covers the investigation of the students' readability in mastering English material especially grammar in the area of simple past tense. Therefore, the writer of this paper conducts the research entitled "Investigating the Students' Readability in Mastering English Material." The topic also provides the pedagogical implication to the English Education in teaching and learning grammar 


\section{Grammar Class}

Ideally, the students of English Education Department of Universitas Muria Kudus have to master grammar materials since they are prepared to be English teachers. Grammar is one of the language elements in English. In Grammar class, teachers or lecturers need to know the rules of grammar in order to make the students use grammar effectively (Crawford, 2013). Furthermore, the students have to be active so they will master the grammar materials. Nowadays, in the teaching and learning process, the teacher/lecturer is not the center at class. The teacher/lecturer plays as facilitator and coach for the students. Therefore, the students are the center of learning. They must take a significant role in the class. In this case, the teaching technique used by the teacher/lecturer in grammar class should be based on students' needs and condition. Teaching technique is necessary for the success of the teaching and learning process. There are many techniques used by the teacher/lecturer in teaching grammar. They are Cooperative Learning, Problem Based Learning, Communicative Learning, and others. Every teaching technique has strengths and weaknesses. So, the teacher/lecturer should know the characteristics of each teaching technique.

Selecting appropriate teaching technique in Grammar Class needs a proper preparation from the lecturer. The lecturer has to be well-prepared in preparing the class based on the selected teaching technique. Also, the students also have to prepare themselves to be ready in the class. Students' readiness takes an important role in the successful process of teaching and learning. The students have to be active in the class. They have to give a good response toward the lecturer's performance. The response becomes part of the teaching and learning process. Students' response can be divided into a positive response and negative response. The two classifications make the variation in the learning process.

The positive response and negative response can be influenced by the students' condition and students' surroundings. Positive response creates good habits from the students. Answering teacher's question, giving full attention to the teacher and always doing assignments are examples of students' positive response. Whereas the negative response becomes the teaching and learning process does not run smoothly. Never participating in the class, always shy in the class and never doing assignments are the examples of students' negative response. Students' negative response can be avoided by creating fun and effective class. The lecturers can use the variation of media and make the class more active. Besides, the lecturers have to deliver the materials based on students' needs and interests.

There are many kinds of topics discussed in Intermediate Grammar Class. One of them is Simple Past Tense. Simple Past Tense is one of the essential materials for students. The students have to master Simple Past Tense. Mastering Simple Past Tense is not an easy thing to do for the students of the second semester of 
Universitas Muria Kudus. They have to study hard to master the materials well.

Furthermore, they also have to be active in the class. Mastering the materials becomes the important thing in the teaching and learning process. The students must be creative in the class. They have to find many sources to comprehend the materials. They have to find the materials not only from books but also can be from the internet.

Nowadays, the students can easily download the materials from their gadgets. Also, they also have to enrich their vocabulary by reading many articles in the journal. They can find the national and international journal. The articles in the journal are up to date since the authors of the articles always write the topics based on the trending news. The students should become fast learners to compete with the other students. They can get the variation of materials from online and offline sources. In teaching and learning process, the lecturers should apply StudentCentered Learning. So, the teacher/lecturer is not the only primary source of the materials. The teacher/lecturer plays as facilitator, coach, and model in the class.

In Intermediate Grammar Class, the students come from different cultural backgrounds. They also have a variation of readability/interest. Students' interests and motivations can influence the students' readability. The students of Universitas Muria Kudus are prepared to be English teachers. So, they need to have good manners and attitudes in teaching and learning process. The students' motivation in learning English is significant. Motivation plays a necessary role in English as a Foreign Language class (Long, Ming, \& Chen, 2013). It can be classified into intrinsic motivation and extrinsic motivation. Intrinsic motivation comes from the students themselves while extrinsic motivation comes from outside of the students. Students' interests belong to intrinsic motivation which can help the students in comprehending the materials. While habit, society and existing beliefs are extrinsic motivation which also can help the students in teaching and learning process.

\section{Simple Past Tense}

In this study, the writer focused on the language component. She limited her study on grammar. She discussed Simple Past Tense. Simple Past Tense becomes the main topic in this study because it is essential for students to be mastered. Simple Past Tense is used to talk about past events. In daily life, the students always use simple past tense. It is one of the topics in Intermediate Grammar Class. In the simple past tense, the students have to understand the verb used. Simple Past Tense use past verb or verb 2. The students have to understand the changes in the verbs. They are sometimes tricky to use the changes of the verb since in the Indonesian language there is no change of the verb. So, as English as a Foreign Language learners, the students have to comprehend the grammar well. They have to implement proper grammar in the sentences. 
Simple Past Tense can be used in recount text. Recount text is one of the genres which has a social function to tell past events. So, recount text uses simple past tense. Simple past tense becomes a very useful tense since it is one of the basics tenses. It can be used to retell about past experience. In the Intermediate Grammar Class, the lecturer and the students discussed the form, the use and the example of simple past tense. In her class, the lecturer applied Student-Centered Learning. So, the students must be active in the class. They had to work in a group in the discussion. The students enjoyed the class. IT can be seen from their performance in responding the lecturer's questions. The students used the time effectively in Intermediate Grammar Class. They did cooperative among the students in the discussion. The spoken grammar will also encourage English language teachers/lecturers (Hilliard, 2014).

In Intermediate Grammar Class, the lecturer taught the materials of simple past tense in context. She related simple past tense with a real-life situation. She selected the materials based on students' needs and interests. Students' needs and interests become the points for teaching and learning process. When the students are interested in something, they will quickly follow and comprehend the materials.

On the other hand, when the students are not interested in something, they will not be seriously in the class. So, the lecturer has to be active and creative in selecting the exciting materials and effective teaching technique. Teaching grammar should be based on context slightly based on the formula, and it will be more meaningful (Zhuang, 2010).

The lecturer has to teach grammar communicatively to improve the students' competence and use it communicatively in communication (Ho \& The Binh, 2014). Real life situation is a good example in context for lecturer and students. They can explore the real-life context which is appropriate for them. They can discuss the topics about students' past experience. It would be fun because every student has a different experience to be discussed with the other students. The lecturer also can download the materials from the internet to make the class vary. Variation of the class can be from the use of teaching media. So, the lecturer has to be creative and active in teaching and learning process in the class.

\section{Students' Readability}

In this digital era, the people are comfortable in doing everything. By using their gadget, they can communicate with the people around the world. In the level of education, the students also get the benefit from their gadgets. The students can use their gadgets anywhere and anytime. In the class, they also can easily use their gadgets. There are some lecturers do not allow their students to use gadgets in the class.

On the other hand, there are some other lecturers allow the students to use gadgets in 
the class. This condition happens in every class. When the lecturers allow the students to use gadgets in the class, they think that gadgets can help the students in mastering the materials. Gadgets also can break the students' concentration when they do not use effectively. Usually, the students use the gadgets to explore their social media. It can break the teaching and learning process in the class.

The students can do many activities through their gadgets. They can listen to music, watching English movies, download articles from the journal, and others. They can improve language skills and language components by using gadgets. The students can do many things based on their readability/interests. The students spent much time to do their readability. Students' readability means the students' interest toward something. Students' readability influences the students' performance in the class.

There are many kinds of students' readability. This study limited on the students' readability in watching English movies. By watching English movies, the students get some benefits. The movie can improve students' language learning, and it can improve students' motivation (Kabooha, 2016). The students can also improve their vocabulary after they watch English movie. Besides, they will know English cultures. The students can also improve their verbal ability by watching an English movie. The lecturer can also teach the students about personal values from the movie (Griffin \& Sherriffs, 1994). English movie is one of the authentic English materials for students. For example, the lecturer may ask the students to watch about American movies; then the lecturer also teaches the students about.

The lecturer and the students can discuss the English movie in the class. The lecturer can ask the students to present about the English movie and the English cultures in the movie. Approaches to the concept of teaching cultural competence have been changing (Piatkowska, 2015).

\section{Research Method}

The research design of this study belongs to descriptive qualitative. This study investigates the students' readability in mastering English material. It focuses on simple past tense. Simple past tense was one of the teaching materials in Intermediate Grammar Class of English Education Department of Teacher Training and Education Faculty of UniversitasMuria Kudus. Besides, the study also describes pedagogical implication to English Education Department.

\section{Participant}

The study was conducted in the English Education Department of Teacher Training and Education Faculty of UniversitasMuria Kudus. The participants were the second-semester students who joined Intermediate Grammar. There were 15 (fifteen) students involving in this research. They were selected based on the readability in watching English movies. 


\section{Instrument}

The paper used two kinds of instrument. They are testing sheet and questionnaire. The test sheet is used to know the students understanding in mastering the material. There were thirty questions in the test sheet. The material in this study is limited in Simple Past Tense. Moreover, the questionnaire was delivered to know the students' readability.

\section{Data Analysis}

In analyzing the data, the writer did the following steps:

1. Calculating the result of the students' test

2. Presenting the data of the result of the students' test

3. Counting the mean score

4. Analyzing the result of the questionnaires

5. Interpreting the data of the result of the instruments

\section{Finding}

The finding of the study reveals about the students' readability in mastering Simple Past Tense.

\section{Simple Past Tense Test}

There were 15 students involved in this study. They were the students of Intermediate Grammar Class. They were the second-semester students of English Education Department of Teacher Training and Education Faculty of UniversitasMuria Kudus. In administering the test, the writer focused on simple past tense. There were 30 questions in the test. The test belongs to multiple questions test. The result of the test shows that the maximum score is 87 while the minimum score is 73. The writer presented the result of the students' test score into the table of the frequency distribution and the histogram data of the students in comprehending the material about Simple Past Tense. She classified the result as follow:

Table 1.The Frequency Distribution of the Students' Test Score in Comprehending the Material about Simple Past Tense

\begin{tabular}{|c|c|}
\hline Score Group & $\mathbf{f}$ \\
\hline $87-90$ & 1 \\
\hline $83-86$ & 1 \\
\hline $79-82$ & 4 \\
\hline $75-78$ & 5 \\
\hline $71-74$ & 4 \\
\hline Total & 15 \\
\hline
\end{tabular}


Figure 1. The histogram of the students in comprehending the material about Simple Past Tense

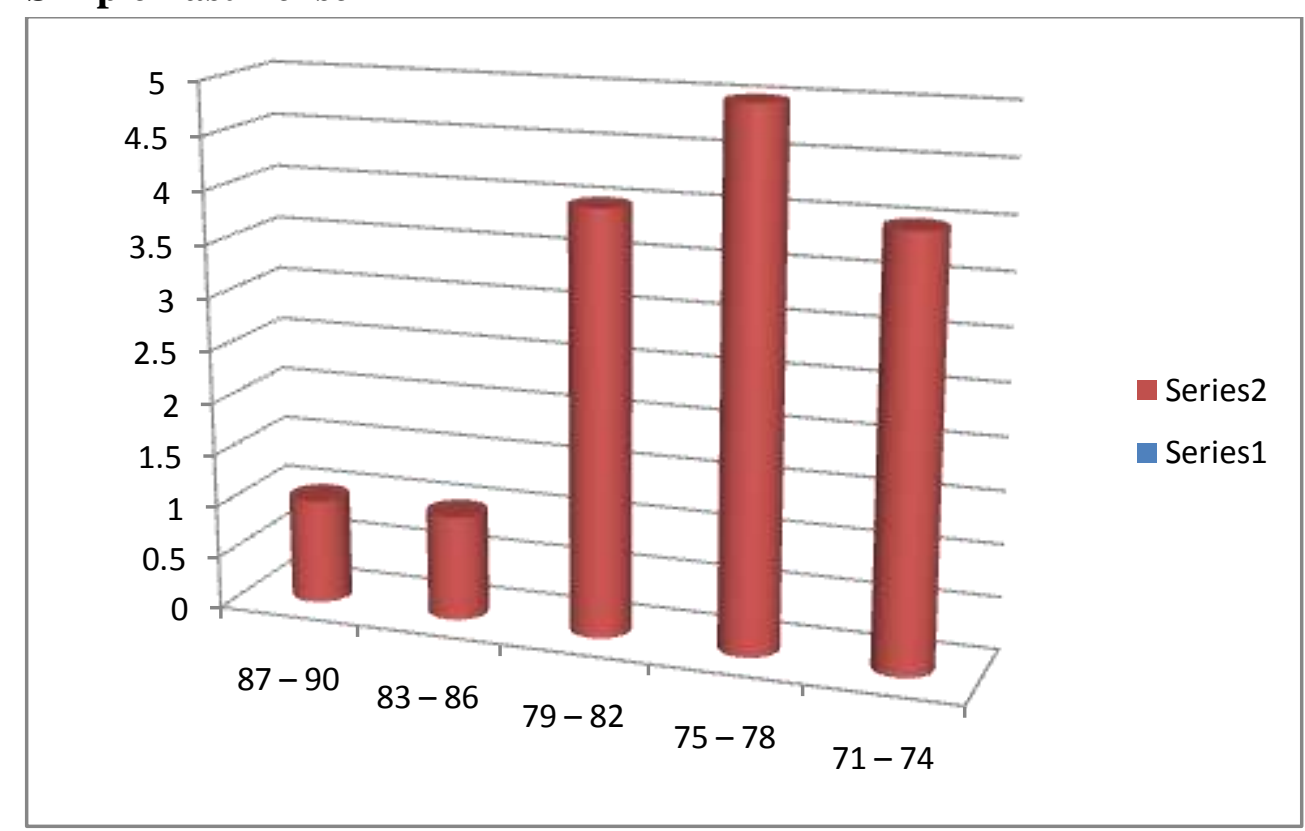

After that, the writer measured the mean score of the students' test. The mean of the students' score was 77.83. It is categorized into good.

\section{Questionnaire}

The questionnaire is also one of the instruments in this study. The writer gave the questionnaire to the students to know their readability. Then, the writer chose the result of the students who like watching TV in Intermediate Grammar Class. There were 15 students involved in the study. The questionnaire belongs to open-ended questions. It is used to know the extent to which the students toward their readability of watching English movies. The finding of this study stated that the students' interest in watching English movies gives a positive effect on the students' achievement in mastering Simple Past Tense. It is in line with the previous research from (Rix, 2012) who stated that there is increasing participation from the students' interests after the instructor's modification.

\section{Discussion}

Based on the finding of the research about the Simple Past Tense Test, the writer relates to the main topic in this study. She focused on the students' readability in mastering Simple Past Tense. Students' readability in this study only focused on watching an English movie. Watching English movie is considered as the relevant topic to be discussed since it has many advantages for students. By watching the English movie, the students can improve their language skills and language components. The students can improve their verbal ability and can improve their 
vocabulary. Also, the students can learn English cultures from the movie.

In Intermediate Grammar Class, the lecturer and the students can also discuss Simple Past Tense from the movie. The lecturer can ask the students to analyze the tenses, especially simple past tense. After that, the students can discuss together with the other students.

In selecting the participants in this study, the writer used Intermediate Grammar Class. Intermediate Grammar Class is taught for the second-semester students of English Education Department of Teacher Training and Education Faculty of UniversitasMuria Kudus. The writer gave the test to students about simple past tense. After that, the writer calculated the result of the students' test. The highest score was 87 while the lowest score was 73 . The writer also calculated the mean of the score. The mean of the students' score was 77.83 .

The writer of the study also distributed the questionnaire to the students of Intermediate Grammar. She got the result that there were 15 (fifteen) students had students' readability on watching English movie. From the questionnaire, the writer of this study got the information that the students watch an English movie due to some consideration.

1. The students will get new vocabulary from English movies

2. They can improve their speaking skill

3. They can learn English culture from the movies

4. They will know Authentic English produced by characters of the movies

Also, the result of the questionnaire stated that some students prefer to watch English movies than listening to English songs. This condition happened because by watching English movies they will get more chance to improve their knowledge. They spend the time to watch English movies in their free time when they have no class. Sometimes, the students enjoy watching English movies with their friends. They usually download movies from the internet. Some of them like watching movies in the cinema.

Most of the students stated that watching English movies can refresh their mind. They also will be happy after they watch new movies. They can share the movies with their friends. They can share the story, the characters, and the moral values to their friends.

The study has pedagogical to English Education Department. The lecturer can ask the students to watch an English movie because by watching an English movie, the students will get some advantages. English movie should be based on students' interests. Also, the lecturers have to pay attention in selecting appropriate teaching techniques, media, and materials of instruction. 


\section{Conclusion}

Students' readability on watching an English movie can be used to improve students' language skills and language components. By watching an English movie, the students will learn about authentic materials of English used by the characters of the English movies. Also, English movie can influence the students' achievement. It can be seen from the result of students' test sheet that like English movie can be categorized into sufficient. The mean of the participant involving in this study is 77.83. There are some benefits that the students got after watching English movies. The students can enrich their vocabulary, and they also will get new information related to western culture. So, the teachers or lecturers can ask the students to watch English movies as the assignments in the class or outside of the English as a Foreign Language class. 


\section{References}

Begeny, J. C., \& Greene, D. J. (2014). Can Readability Formulas Be Used to Successfully Gauge Difficulty of Reading Materials? Psychology in the Schools, 51(2), 198-215. https://doi.org/10.1002/pits.21740.

Crawford, W. J. (2013). Teaching Grammar. TESOL International Association.

Griffin, K., \& Sherriffs, E. (1994). Teaching Values through American Movies. Retrieved from http://eric.ed.gov/?q=english+movie\%2c+vocabulary\&id=ED373543

Hilliard, A. (2014). Spoken Grammar and Its Role in the English Language Classroom. English Teaching Forum, 52(4), 2-13.

Ho, P. V. P., \& The Binh, N. (2014). The Effects of Communicative Grammar Teaching on Students' Achievement of Grammatical Knowledge and Oral Production. English Language Teaching, 7(6), 74-86.

Kabooha, R. H. (2016). Using Movies in EFL Classrooms: A Study Conducted at the English Language Institute (ELI), King Abdul-Aziz University. English Language Teaching, 9(3), 248-267.

Piatkowska, K. (2015). From Cultural Knowledge to Intercultural Communicative Competence: Changing Perspectives on the Role of Culture in Foreign Language Teaching. Intercultural Education, 26(5), 397-408. https://doi.org/10.1080/14675986.2015.1092674.

Rix, S. (2012). The Role of Interest Enhancement for L2 Learners. Journal on English Language Teaching, 2(3), 28-34.

Srichanyachon, A. N. (2013). The Use of Internet of EFL Learners. Turkish Online Journal of Distance Education, 14(4), 320-327.

Zhuang, X. (2010). Grammar Learning and Teaching: Time, Tense and Verb (Vol. 7). Retrieved from http://eric.ed.gov/?id=ED514903 